\title{
The impact of brand positioning and knowledge on attitude towards brand and purchase intention: A study of organic rice in Ho Chi Minh City
}

\author{
Hoang Thi Phuong Thao ${ }^{1 *}$, Lu Van Bao Long ${ }^{1}$, Nguyen Le Thai Hoa ${ }^{2}$ \\ ${ }^{1}$ Postgraduate school, Ho Chi Minh City Open University, Vietnam \\ ${ }^{2}$ Business Administration School, Saigon Technology University (STU), Vietnam \\ ${ }^{*}$ Corresponding author: thao.htp@ou.edu.vn
}

\begin{tabular}{|c|c|}
\hline ARTICLE INFO & ABSTRACT \\
\hline $\begin{array}{l}\text { DOI: } 10.46223 / \text { HCMCOUJS. } \\
\text { econ.en.10.1.225.2020 }\end{array}$ & $\begin{array}{l}\text { The purpose of this study is to measure the effectiveness of } \\
\text { factors of brand, including Brand Positioning, Brand Knowledge, } \\
\text { Attitude towards Organic Rice Brand, and Organic Rice Purchase }\end{array}$ \\
\hline Received: September $16^{\text {th }}, 2019$ & Intention. The survey was conducted with a sample of 224 \\
\hline Revised: January $14^{\text {th }}, 2019$ & consumers shopping at four organic rice shops in Ho Chi Minh \\
\hline Accepted: April $10^{\text {th }}, 2020$ & $\begin{array}{l}\text { City. The research was performed by quantitative research } \\
\text { methods: Cronbach's Alpha Reliability Analysis, Exploratory } \\
\text { Factor Analysis (EFA), Confirm Factor Analysis (CFA), and }\end{array}$ \\
\hline $\begin{array}{l}\text { Keywords: } \\
\text { organic rice, brand positioning, } \\
\text { brand knowledge, attitude } \\
\text { towards the brand, organic rice } \\
\text { purchase intention }\end{array}$ & $\begin{array}{l}\text { Structural Equation Modeling (SEM). The research results were } \\
\text { conducted in two direct models and the indirect models in which } \\
\text { the indirect model was supported. This means that brand } \\
\text { positioning and brand knowledge had no direct impact on the } \\
\text { Intention to buy organic rice, but only an indirect one through the } \\
\text { consumer attitude towards the organic rice brand. }\end{array}$ \\
\hline
\end{tabular}

\section{Introduction}

In recent years, the status of poor - quality food is a critical problem in Vietnam. Nevertheless, recent news about poor quality rice produced from plastic or mixing anti-mold chemicals or marinated chemical aromatic is increasing. Ho Chi Minh City is a hot spot for these poor - quality deals. This brings a bad image for a country with the world's largest rice export volume like Vietnam. In the world today, organic products are always concerned, because it is good for health and does not harm the environment. Vietnam is an agricultural country with strengths in rice cultivation, so it is possible to create organic rice products of international standards. Until May 2017, the whole Ho Chi Minh City market has 8 brands of organic rice. Their process is ensured from planting, harvesting, and milling rice. Four brands of organic rice are certified from reputable organic standard certification organizations in the world, such as Hoa Sua, Eco rice, OrgaGro, and Coop Organic. However, consumers still confuse to recognize the difference between normal rice and organic rice and managers also confuse to position the brand of organic rice into the customers' minds. This real situation leads to a question: "Whether consumers understand the concept of organic rice? or because no business has succeeded in building its own Organic Rice Brand?". 
Nowadays, consumers around the world are increasingly demanding organic products, organic rice is a sample, and past research has highlighted some relevant issues about organic food management, but there is a lack of research examining the effects of consumer perceptions of organic food marketing strategies toward green behaviors (Cronin, Smith, Gleim, M, Ramirez, \& Martinez, 2011) as well as only a few studies have focused on organic food branding. Typically, Hughner, Mcdonagh, Prothero, and Shultz (2007) studied the factors of choosing organic food. Suki (2016) focused on the survey of organic food consumers in Malaysia or Huang, Yang, and Wang (2014) surveyed the members of Taiwan's Healthy and Sustainable Lifestyle Club for Toyota's hybrid cars. Research by C. C. Teng and Wang (2015) explored the information presented on organic food labels and the perception of organic food knowledge on consumers' beliefs and attitudes, then influencing the organic product purchasing intention. These researches have not been explored the impact of organic food brand factors (brand positioning and brand knowledge) on consumers' attitudes and purchase intention. Moreover, most of these studies have focused on green products or generic organic foods but have not gone into specific studies for organic rice. In Vietnam, studies on the effects of brand factors and consumers' attitudes towards organic rice brands on purchasing intention have not been considered yet.

Therefore, to fill the research gap about organic food brand issues, the study: "The impact of brand positioning and knowledge on the attitude towards brand and purchase intention: A study of organic rice in Ho Chi Minh city" was conducted. The research results may help organic rice companies to improve brand positioning and knowledge so that consumers will have more positive awareness and attitude in consuming organic rice.

\section{Literature review}

\subsection{Main concepts}

\subsubsection{Organic rice}

Organic rice is a plant-based organic food that has all the properties of organic food. Organic rice is grown and grown organically in a closed process to ensure cleanliness, no use of genetically modified rice, no chemical fertilizer, no pesticides, and stimulants, like growth, pest control process using light trap method, releasing birds to eat insects, eliminating pests by manual methods. Farmers do not use chemical flavoring to season rice. Especially organic rice is not polished (must be whole).

\subsubsection{Brand positioning}

Brand positioning is all about creating the optimal location in the minds of existing and potential customers so that they think of the brand in the "right way". Brand positioning requires thoughtful analysis of competitors and consumers to determine the desired image for the brand to maximize its chances for success. Although a few different approaches and methodologies for positioning are possible, they all typically define the nature of the target market and relevant competitors and the means of how the brand should be similar as well as distinct from those competitors (Keller, 1999).

A closely related - but distinct - concept is core brand associations. Core brand associations are those consumer-derived associations that reflect brand positioning. In other words, core brand associations are those brand associations in the minds of consumers that are created or reinforced as a result of the firms' marketing activity to convey the desired positioning. The effectiveness of the marketing program will be the extent to which strong, favorable, and unique brand associations 
are created as a result of consumer experiences with the marketing program that reflects the intended positioning (Keller, 1999).

Core brand associations may be tangible or intangible attributes or benefits, experiences, images - anything that can be stored in memory and linked to the brand that reflects its brand positioning. Core brand associations are important to define so that efforts to measure brand equity, e.g., through brand tracking, are pointed in the right direction and able to tap into consumer brand meaning in a relevant way. Core brand associations may also help to suggest the proper language and phrasing be used for the brand internally within the organization (Keller, 1999).

\subsubsection{Brand knowledge}

Brand knowledge is what consumers have learned, felt, seen, and heard about the brand as a result of their experiences over time. According to Keller (1993), Brand knowledge has two components: Brand awareness and brand image. Brand awareness is related to the strength of the brand node or trace in memory, which we can measure as the consumer's ability to identify the brand under different conditions. Brand awareness consists of brand recognition (consumers' ability to confirm prior exposure to the brand when given the brand as a cue) and brand recall (consumers' ability to retrieve the brand from memory when given the product category, the needs fulfilled by the category, or a purchase or usage situation as a cue). Brand image is consumers' perception of a brand, as reflected by the brand associations held in consumer memory. In other words, brand associations are the other informational nodes linked to the brand node in memory and contain the meaning of the brand for consumers. Associations come in all forms and may reflect characteristics of the product and aspects independent of the product.

\subsubsection{Attitude towards brand}

The attitude towards a brand is consumer preference and overall rating of a brand, which symbolizes their likes and dislikes (Solomon, 2014). There are many models of attitude, however, the model of the tricomponent attitudes of Schiffman and Kanuk (2000) is more acceptable and includes three basics: cognitive component, emotional (affective component), and tended behavior. In practice, many studies showed that three elements were often grouped into two components, in which the emotional feelings and behavioral tendencies were united.

\subsubsection{Purchase intention}

Purchase intention can be classified as one of the components of consumer cognitive behavior on how an individual intends to buy a specific brand. The theory of reasoned action assumes that individual is rotational and make systematic use of the information available to them (Fishbein \& Ajzen, 1975); that is, the individual's attitude affects a person's behavioral intention.

There are quite a few studies on purchase intention, most of which are based on the theory of consumer behavior with the theory of reasoned action (TRA) of Fishbein and Ajzen (1975) and theory of planned behavior (TPB) of Ajzen (1991) that have been applied in the most of research because they clarified the relationship between intended behavior and attitude of a person. Therefore, this research also used these two theories as to the basis.

\subsection{Hypotheses development and research model}

\subsubsection{Organic rice brand positioning and purchase intention}

Brand positioning is the message that businesses choose to send to consumers. Researchers 
have emphasized that brand positioning must meet consumers' expectations so that they could associate the brand with its valuable attributes (Wang, 2016). Suki (2016) proved that green product brand positioning had an impact on the intention to buy green products. Consumers' understanding of the environment and active eco-friendly product procurement experience in the past leads to the tendency of buying green products strongly through the specified green brand positioning (Lin \& Chang, 2012; Norazah, 2013). This trend changes according to the environmental awareness of consumers and the use of products. Therefore, green brand positioning, through positive communication campaigns related to green attributes, can create a more positive awareness of green brands in consumers' minds. The researchers had previously confirmed that green brand positioning influenced the intention to buy green products (Huang et al., 2014; Mostafa, 2009). Therefore, the first hypothesis is proposed as follows:

H1: Organic rice brand positioning positively impacts on organic rice purchase intention

\subsubsection{Organic rice brand positioning and attitude towards organic rice brand}

Some studies confirmed that the level of consumers' awareness of the environment increased their attitude towards eco-friendly brands since they have realized the worthy actions on the environment from entrepreneurs (Becker-Olsen, Cudmore, \& Cudmore, 2006). Patrick, Ibanez, and Sainz (2005) also argued that green brand positioning could have a positive effect on consumers' attitudes towards green brands. Indeed, the study of Mostafa (2009) showed that a positive attitude towards green products tended to purchase green products by referring to the brands with green positioning. This study proposes the following research hypothesis:

brand

H2: Organic rice brand positioning positively impacts on attitude towards organic rice

\subsubsection{Organic rice brand knowledge and purchase intention}

Brand knowledge is what consumers recognize from the signals and messages that businesses send to them. Consumers want to receive reliable information on environmental issues to enhance their green brand knowledge and facilitate the purchase of green products (Ganapathy, Natarajan, Gunasekaran, \& Subramanian, 2014; Geyer-Allely \& Zacarias-Farah, 2003).

Numerous studies have shown that environmental knowledge positively influenced consumer purchasing intentions and the actual purchase of green products (Chen \& Chang, 2012; Mostafa, 2009; Pagiaslis \& Krontalis, 2014; Yadav \& Pathak, 2016). These results also supported the research of Paul, Modi, and Patel (2016).

In addition, consumers with a high level of green brand knowledge are more environmentally friendly and have stronger purchase intention of green products (Huang et al., 2014). Suki (2016) admitted that green brand knowledge had an impact on the green brand purchase intention. Accordingly, this study suggests that:

H3: Organic rice brand knowledge positively impacts on organic rice purchase intention

\subsubsection{Organic rice brand knowledge and attitude towards organic rice brand}

Some green marketing studies stated that the participation of consumers with environmental issues will enhance their awareness of the environment (Oliver \& Lee, 2010). Besides, Smith and Paladino (2010) suggested that knowledge of organic foods positively affected the attitudes toward organic foods. 
Experience of brand knowledge in the past and present are part of consumers' awareness and participation to assess comprehensively the brand. The research on greenfield awareness has shown that knowledge and awareness of the environment affected the consumers' attitude towards the environment (Mostafa, 2007). From research on consumers in Egypt, Mostafa (2007) found that getting knowledge on the environment was a good predictor of attitudes on ecological goodwill. Previously, Aaker and Joachimsthaler (2002) also argued that brand knowledge improved the attitude towards the brand. Furthermore, Suki (2016) and Huang et al. (2014) also verified that green brand knowledge had a positive impact on attitudes towards green brands. As such, this study proposes the following hypothesis:

H4: Organic rice brand knowledge positively impacts on attitude towards organic rice brand

\subsubsection{Attitude towards organic rice brand and purchase intention}

Some studies suggested that attitudes towards brands influenced purchase intention (L. Teng, 2009). Providing an eco-friendly attribute effectively to consumers helps the consumers to give preference for this eco-friendly brand over other competing brands in the market (Rios, Martinez, Moreno, \& Soriono, 2006). Previous green marketing studies have shown that consumers' attitudes towards eco-friendly behavior significantly influence the purchase intention on green products. Accordingly, Yadav and Pathak (2016) confirmed that consumers' attitudes towards green products had a significant influence on buyers' green consumption intention. In parallel with these findings, Paul et al. (2016) noted that the attitude of Indian consumers significantly predicted their purchase intention on green products. A research effort by L. Teng (2009) further determined that consumers who had a positive attitude towards a brand would be more likely to buy that brand. Also, Suki (2016) and Huang et al. (2014) also asserted that attitude towards green brands had a significant impact on the green purchase intention. Therefore, this study proposes the following hypothesis:

H5: Attitude towards organic rice brand positively impacts on organic rice purchase intention

From the above-mentioned hypotheses, the research model is described as follows:

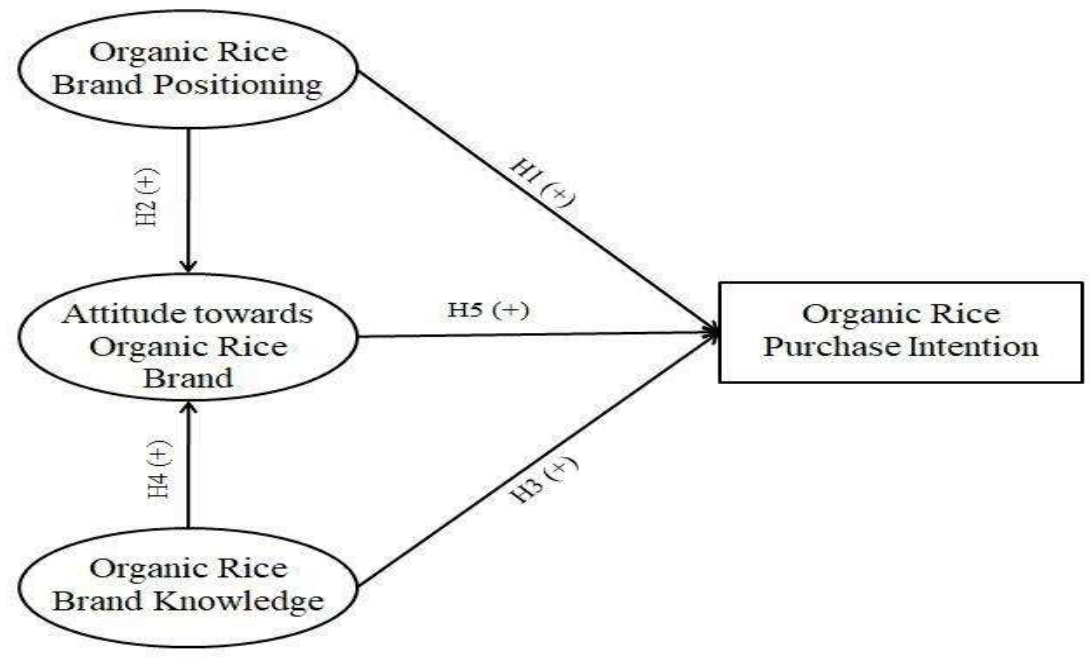

Figure 1. The proposed research model 


\section{Methodology and research data}

The study used a mixed model of both qualitative and quantitative methods with quantitative methods as the key. The qualitative research was divided into two groups: expert group ( 4 business owners who were trading organic rice in Ho Chi Minh City) and consumer group (10 consumers who met the filtering conditions: food decision-maker in the family, living in Ho Chi Minh City, used to buy and used organic rice in the past 3 months at 3 organic food stores) to explore new observable items and to adjust and complete the constructs in the research model.

Quantitative data was collected through a paper questionnaire. Likert scale includes 5 intervals as follows to measure observed variables: 1: strongly disagree, and 5: strongly agree. More than 270 questionnaires were distributed in a convenient sampling method; in which, 243 questionnaires were collected, accounting for $90 \%$ of the total. Collected responses were checked carefully and invalid ones were eliminated. Invalid questionnaires were those with the same answers for most of the questions or marked answers with zigzags and unfinished ones. Lastly, 224 responses were eligible for data analysis.

\section{Research results}

\subsection{Descriptive statistics}

In the sample size of $224,94.6 \%$ are female while only $5.4 \%$ are male, which is quite consistent with screen conditions that women are still the ones who decide what food to buy for the family. Regarding age, the age group from 25 to 45 accounted for $60.3 \%$. The highest level of education is university and postgraduate, accounting for $70.54 \%$. In the observed variable of occupation, office staff make up the majority of $35.7 \%$. This is consistent with the fact that most of the highly educated consumers will have more knowledge and interest in organic food in general, more specifically, the benefits of organic rice. The sample description shows that: the survey sample is not equal in terms of age group, income, occupation, brand purchased, and residence so the representation of the collected sample is partly limited.

\subsection{Results of measurement scale}

\subsubsection{Testing the scales of constructs by EFA and Cronbach's Alpha}

Performing a measurement scale with 04 variables and 20 items in the study, the results showed that Cronbach's Alpha ranged from 0.831 to 0.897 (greater than 0.3). After eliminating three items BK1, BK3, and BK5, the Cronbach's Alpha coefficient of "Brand knowledge" increased 0.858 respectively.

After analyzing the reliability of the scale through Cronbach's alpha coefficient, the study was left with 17 items eligible for EFA analysis. The method "Principal axis factoring" and nonsquare rotation of Promax were used. The EFA results showed that 17 items had 4 extracted factors (equal to the number of factors of the proposed research model). All indicators had the factor loading ranging from 0.624 to 0.859 (all greater than 0.5 ). KMO coefficient was 0.815 which satisfies the condition of KMO coefficient. Bartlett's Test of Sphericity test had a value of Sig = 0.000 , which means that the variables are related to each other. The total variance extracted by 61,784 at the Eigenvalues value of 1.748 (greater than 1). With the above EFA test results, the extraction of this factor is consistent with the test values. 
Table 1

EFA and Cronbach's Alpha results

\begin{tabular}{|c|c|c|c|c|c|c|}
\hline \multirow{2}{*}{ No } & \multirow{2}{*}{ Items } & \multicolumn{4}{|c|}{ Component } & \multirow{2}{*}{$\begin{array}{c}\text { Component } \\
\text { name }\end{array}$} \\
\hline & & 1 & 2 & 3 & 4 & \\
\hline 1 & $\mathrm{BP} 2$ & .844 & & & & \multirow{5}{*}{$\begin{array}{c}\text { Organic Rice } \\
\text { Brand Positioning }\end{array}$} \\
\hline 2 & BP3 & .833 & & & & \\
\hline 3 & BP5 & .793 & & & & \\
\hline 4 & BP4 & .780 & & & & \\
\hline 5 & BP1 & .743 & & & & \\
\hline 6 & BK7 & & .853 & & & \multirow{5}{*}{$\begin{array}{c}\text { Organic Rice } \\
\text { Brand } \\
\text { Knowledge }\end{array}$} \\
\hline 7 & BK8 & & .818 & & & \\
\hline 8 & BK6 & & .738 & & & \\
\hline 9 & BK4 & & .699 & & & \\
\hline 10 & BK2 & & .624 & & & \\
\hline 11 & $\mathrm{AB} 2$ & & & .839 & & \multirow{4}{*}{$\begin{array}{c}\text { Attitude towards } \\
\text { Organic Rice } \\
\text { Brand }\end{array}$} \\
\hline 12 & $\mathrm{AB} 1$ & & & .827 & & \\
\hline 13 & $\mathrm{AB} 4$ & & & .746 & & \\
\hline 14 & $\mathrm{AB} 3$ & & & .633 & & \\
\hline 15 & PI1 & & & & .859 & \multirow{3}{*}{$\begin{array}{l}\text { Organic Rice } \\
\text { Purchase } \\
\text { Intention }\end{array}$} \\
\hline 16 & PI4 & & & & .835 & \\
\hline 17 & $\mathrm{PI} 2$ & & & & .712 & \\
\hline \multicolumn{2}{|c|}{ Cronbach Alpha } & 0.897 & 0.858 & 0.831 & 0.845 & \\
\hline
\end{tabular}

Source: Data analysis result of the research

\subsubsection{Results of Confirmatory Factor Analysis (CFA)}

After analyzing the reliability of the scale through Cronbach's alpha and EFA coefficients, the study consisted of 17 indicators eligible for CFA analysis implementation. CFA analysis results show that the scale has met the testing requirements. 


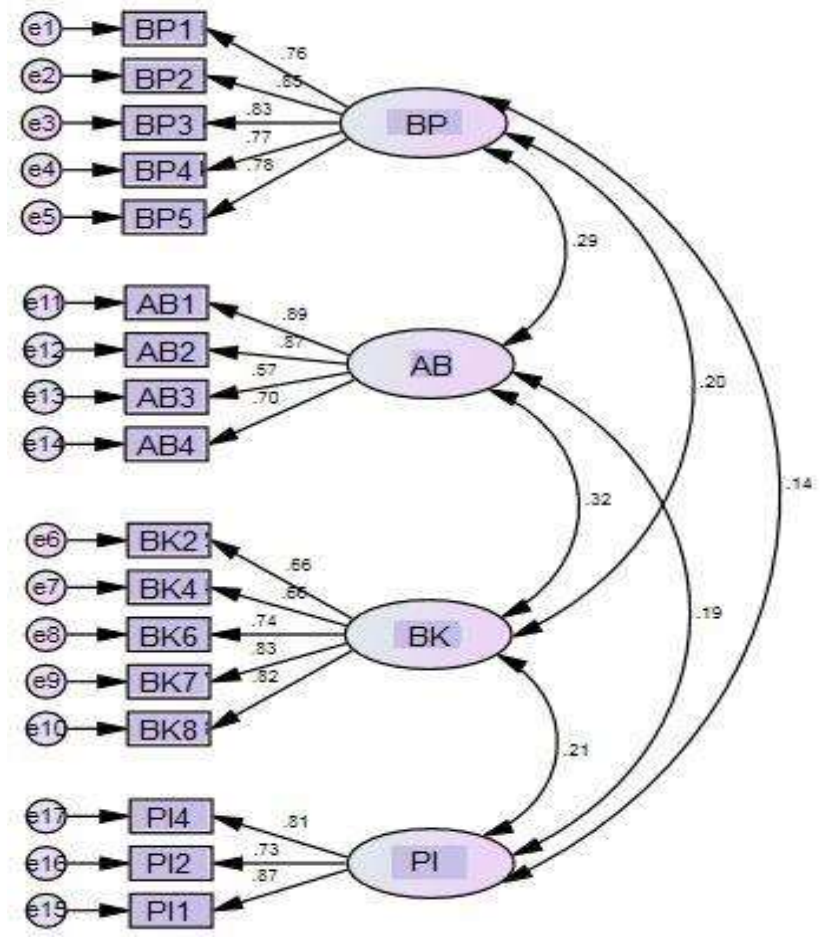

Figure 2. CFA result for full measurement (standardized estimate)

\section{- Evaluating model fit}

The test results showed that Chi-square $=207,897 ; \mathrm{df}=113 ; \mathrm{p}=0,000 ;$ Chi-square $/ \mathrm{df}=$ 1,$840 ; \mathrm{CFI}=0.951, \mathrm{GFI}=0.93$ and TLI $=0.941 ; \mathrm{RMSEA}=0.061$. Therefore, the model guarantees a general relevance level. These values represent the compatibility of the model with market data and ensure unidirectionally.

\section{- Reliability test}

The total reliability coefficient (CR) ranges from 0.847 to 0.898 and the total variance extracted for each factor ranges from $56.037 \%$ to $65.039 \%$. This shows that the scale ensures reliability.

\section{- Convergent validity}

The loading coefficients of the observed variables on the corresponding factors range from 0.565 to 0.885 . In addition, the average variance extracted is greater than $50 \%$ that higher than all correlation coefficients and the combined reliability coefficient is greater than 0.7 for each factor (Hair, Black, Babin, \& Anderson, 2010). Therefore, it can be concluded that the scale ensures good convergence value.

\section{- Discriminant validity}

Checking the correlation matrix between the two concepts in Table 2 shows that the square of the correlation coefficient between the two constructs is smaller than the Average Variance Extracted (AVE) of all the concepts in the model. Therefore, this study reaffirms the scale of concepts in the research model achieved discriminant validity. 
Table 2

Correlation matrix and AVE statistics

\begin{tabular}{|l|l|l|l|l|l|}
\hline \multicolumn{1}{|c|}{ Component } & AVE & BP & AB & BK & PI \\
\hline Brand Positioning (BP) & 0.637 & & & & \\
\hline Attitude towards Brand (AB) & 0.588 & 0.084 & & & \\
\hline Brand Knowledge (BK) & 0.560 & 0.038 & 0.099 & & \\
\hline Purchase Intention (PI) & 0.650 & 0.020 & 0.036 & 0.042 & 1.000 \\
\hline
\end{tabular}

Source: Data analysis result of the research

\subsection{Hypotheses testing by SEM}

In testing these hypotheses, two models were tested: Direct and indirect model. In the direct model, the factor of attitude was played the role of both the independent variable and an intermediate variable. Five hypotheses remained the same as the proposed research model. In the indirect model, the factor of attitude was only an intermediary variable, then $\mathrm{H} 1$ and $\mathrm{H} 3$ were not considered (assigning value equal to " 0 ").

Table 3

Results of hypotheses testing

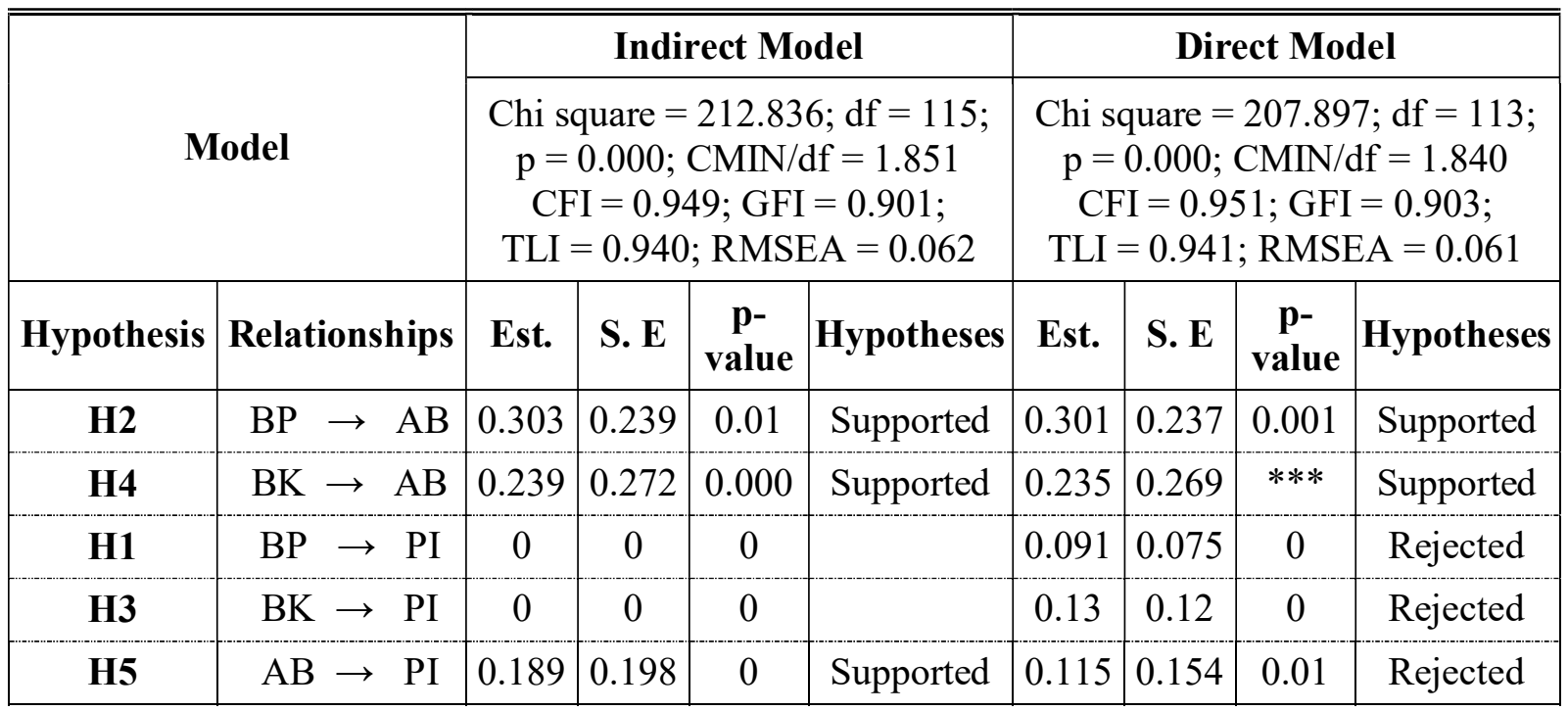

Source: Data analysis result of the research

From the above results, it was shown that both the direct model and the indirect model ensured the overall relevance of the model (CMIN/df $<2$; CFI, GFI, and TLI $>0.9$; RMSEA $<$ 0.07). This meant that both models were suitable for data collected from the market and there was no correlation between measurement errors, so it achieved uniqueness.

The research results from the direct and indirect models showed us that both of $\mathrm{H} 1$ and $\mathrm{H} 3$ were rejected or not considered, which mean that there was no direct impact from positioning and knowledge of organic rice brand to organic rice purchase intention but only indirectly impacted by consumers' attitude towards organic rice. The results showed that the indirect model was more positive and considered. 


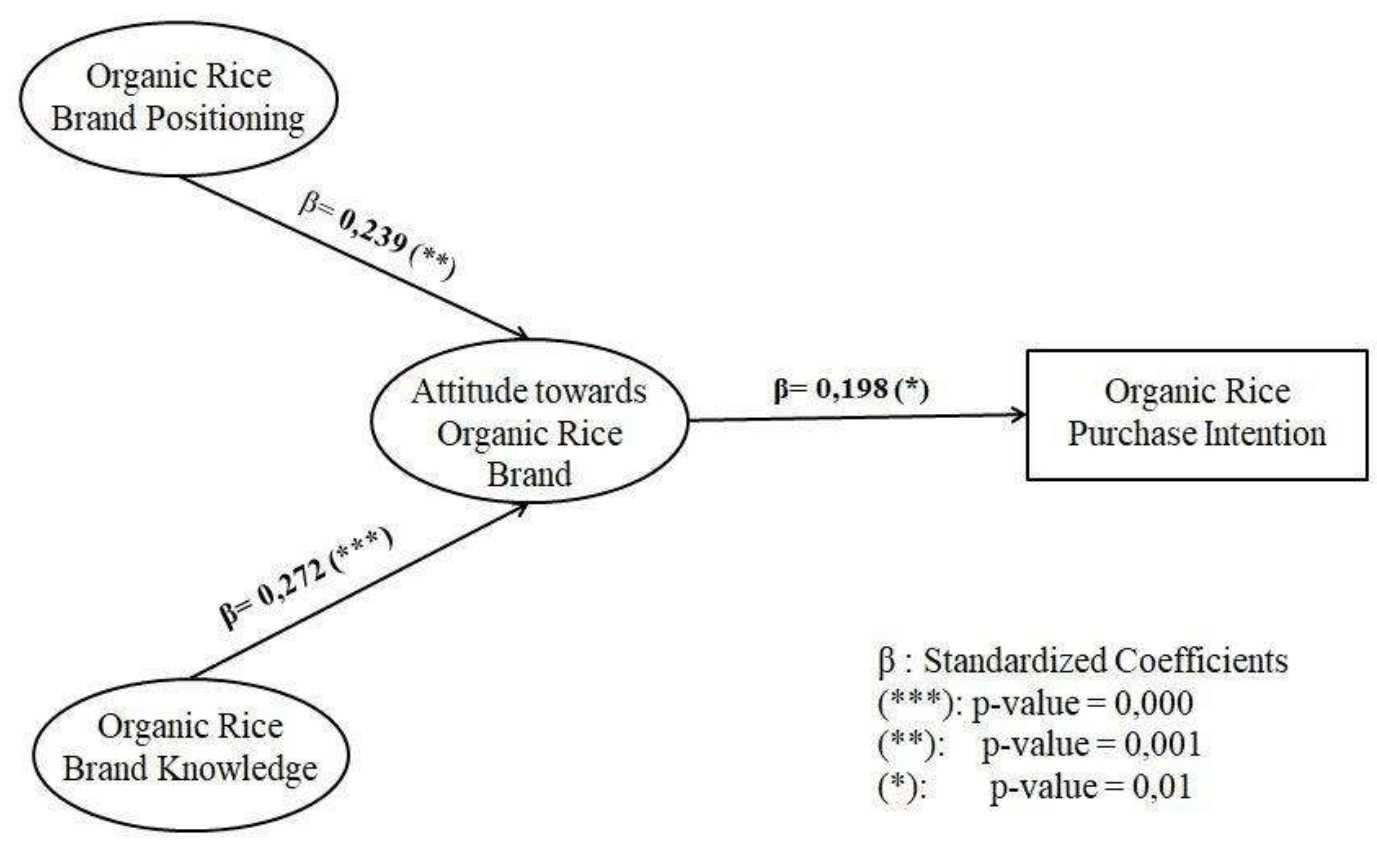

Figure 3. Results Indirect Model (Standardized estimate)

Testing results supporting indirect models showed that $\mathrm{H} 2, \mathrm{H} 4$, and $\mathrm{H} 5$ were statistically significant at a confidence interval of $95 \%$, so they should be supported. In which, the $\beta=0.272$ $(p$-value $=0.000)$ was the highest for the relationship from brand knowledge to consumers' attitude toward organic rice brand, the coefficient $\beta=0.198$ ( $p$-value $=0.01$ ) was the lowest for the relationship between the purchasing intention and the consumers' attitude toward the organic rice brand, the remaining $\beta=0.223$ ( $p$-value $=0.001$ ) for the effect of brand positioning on consumers' attitude toward organic rice brand. This implies that brand positioning and brand knowledge only influence purchasing intention through attitude toward the brand. Therefore, the study concludes that compared to the direct model, the indirect model explains real market data better.

\section{Conclusion and managerial implications}

The paper has a significant contribution to building a comprehensive research model on the impact of brand factors on consumers' attitudes and purchasing intention by examining the perception and assessment of organic rice consumers in Ho Chi Minh City. In this research, two brand factors were determined, including brand knowledge and brand positioning. Our finding exhibits that organic brand knowledge positively influences consumers' attitudes towards the organic brand, that is consistent with the previous research results by Mostafa (2007) and Huang et al. (2014). Moreover, Aaker and Joachimsthaler (2002) also stated that a high awareness and positive image of the brand improve consumers' brand attitudes. Additionally, the empirical result indicates that brand positioning positively effects consumers' attitudes. This is similar to the research of Patrick et al. (2005). Next, the fact that the attitude was found to positively impact purchasing intention in accordance with the theory of planned behavior by Ajzen (1991) and empirical research by L. Teng (2009) and Huang et al. (2014). The final important finding shows that the attitudes towards organic rice brands play a very important and fully intermediary role in the organic rice purchase intention through organic rice brand positioning and knowledge.

The above findings derived from this study provide some following theoretical implications. Firstly, the study developed and examined a comprehensive research framework about the effects of brand factors on purchase intension. Secondly, this study extended the research of brand issues into the field of organic food issues, particularly organic rice, a recently emerging 
topic in Vietnam. Thirdly, our paper used the construct about organic rice brand positioning of firms perceived by consumers that further answers a recent call for a lack of marketing research that evaluates the efficiency of green marketing strategies (Cronin et al., 2011). Fourthly, the survey was conducted with the real consumers who were buying organic rice at organic rice shops instead of student populations as common practice in academic research. This study increases the external validity of the study results. Finally, most previous studies on organic food issues are from the USA and western Europe, this research was based on Vietnamese perspectives on the purpose of filling the geographical context gap on organic food branding.

From the results of the survey and data analysis achieved from the study, some managerial implications are proposed as follows:

Firstly, organic rice companies should propose a specific brand positioning strategy. To improve organic rice sales volume, the companies need to communicate and promote why organic rice is a high-quality product, even though it's only rice for daily needs. Particularly, they highlight very strict farming processes and must ensure countless rigorous criteria to produce organic rice with certificates from reputable organizations around the world.

Secondly, the marketing manager should implement media programs, promoting the brand to increase the understanding of consumers' knowledge for their brands, thereby improving the love and satisfaction for the brand or the consumers' attitude towards the organic rice brands. This is the factor that consumers are most interested in, but there are many different opinions, so the company needs to ensure traceability of quality for their products to increase the trust and favor of customers for their brand. Bar code is recommended on each product packaging for consumers to scan this bar code into the company website to access specific information with illustrative images such as type of rice, where to grow, testing results of soil and water quality at the planting site, any disease or pest attack suffered, how it was handled, and how the insect trap was used.

Thirdly, consumers' attitude towards organic rice brand is an important intermediary factor that influences consumers' purchasing intention. Therefore, the consumers' love and satisfaction of organic rice are very important, and the companies need to meet the most different preferences of each consumer group such as which products are for sticky rice, dry rice, fragrant rice, and so on are clearly shown on the packaging. Proving the quality of company's products with true organic quality ensuring the absolute safety, which requires an effort to communicate to consumers with organic certificates from reputable units like USDA of the US Department of Agriculture or Australian Government OFC, ... and the traceability of the product as mentioned above is also a psychological factor to increase the trust of consumers for quality of organic rice brand of the company.

In summary, the quantitative scientific evidence of this study on the purchasing intention of organic rice by consumers in Ho Chi Minh City nowadays shows the health and nutrition factors that organic rice brings from its quality without using chemicals during planting to ensure safety is of most interest to consumers. Therefore, the brand positioning of organic rice should focus on nutrition and health and must carry on promoting communication to customers so that they know the products which are grown following actual organic standards as certificates from reputable units or traceability of the product is extremely important.

Although certain results have been achieved, this study also has some limitations on the representativeness of the analytical sample which is not high because the study was conducted in Ho Chi Minh City only with a convenient sampling method (non-probability). The study only focuses on relevant factors about organic rice brands like the influence of brand positioning and 
brand knowledge on purchasing intention. So future studies should expand the scope across all areas where organic rice is sold in Vietnam, adding other factors that influence purchasing intention, such as brand trust, subjective norm, etc.

\section{References}

Aaker, D. A., \& Joachimsthaler, E. (2002). Brand leadership. Academy of Marketing Science, 30(2), 175 178.

Ajzen, I. (1991). The theory of planned behavior. Organization Behavior and Human Decision Processes, 50, 197-211.

Becker-Olsen, K. L., Cudmore, B. A., \& Cudmore, R. P. (2006). The impact of perceived corporate social responsibility on consumer behavior. Journal of Business Research, 59(1), 46-53. doi:10.1016/j.jbusres.2005.01.001

Chen, Y. S., \& Chang, C. H. (2012). Enhance green purchase intentions - The roles of green perceived value, green perceived risk, and green trust. Management Decision, 50(3), 502520. doi:10.1108/00251741211216250

Cronin, J. J., Smith, J. Jr., Gleim, M. R., Ramirez, E., \& Martinez, J. D. (2011). Green marketing strategies: An examination of stakeholders and the opportunities they present. Journal of Academy of Marketing Science, 39(1), 158-174. doi:10.1007/s11747-010-0227-0

Fishbein, M., \& Ajzen, I. (1975). Belief, attitude, intention and behavior: An introduction to theory and research. Boston, MA: Addison-Wesley.

Ganapathy, S. P., Natarajan, J., Gunasekaran, A., \& Subramanian, N. (2014). Influence of eco innovation on Indian manufacturing sector sustainable performance. International Journal of Sustainable Development and World Ecology, 21(3), 198-209. doi:10.1080/13504509.2014.907832

Geyer-Allely, E., \& Zacarias-Farah, A. (2003). Policies and instruments for promoting sustainable household consumption. Journal of Cleaner Production, 11, 923-926. doi:10.1016/S09596526(02)00156-7

Hair, Jr., J. F., Black, W. C., Babin, B. J., \& Anderson, R. E. (2010). Multivariate data analysis (6th ed.). Upper Saddle River, NJ: Pearson Prentice-Hall.

Huang, Y. C., Yang, M., \& Wang, Y. C. (2014). Effects of green brand on green purchase intention. Marketing Intelligence and Planning, 32(3), 250-268. doi:10.1108/MIP-10-2012-0105

Hughner, R. S., Mcdonagh, P., Prothero, A., \& Shultz, C. J. (2007). Who are organic food consumers? A compilation and review of why people purchase organic food. Journal of Consumer Behavior, 6(2/3), 1-17. doi:10.1002/cb.210

Keller, K. L. (1993). Conceptualizing, measuring and managing customer-based brand equity. Journal of Marketing, 57(1), 1-22. doi:10.1177/002224299305700101

Keller, K. L. (1999). Brand mantras: Rationale, criteria and examples. Journal of Marketing Management, 15(1/3), 43-51. doi:10.1362/026725799784870513

Lin, Y. C., \& Chang, C. C. A. (2012). Double standard: The role of environmental consciousness in green product usage. Journal of Marketing, 76(5), 125-134. doi:10.2307/41714513

Mostafa, M. (2007). A hierarchical analysis of the green consciousness of the Egyptian consumer. Psychology and Marketing, 24(5), 445-473. doi:10.1002/mar.20168 
Mostafa, M. (2009). Shades of green: A psychographic segmentation of the green consumer in Kuwait using self-organizing maps. Expert Systems with Applications, 36(8), 11030-11038. doi:10.1016/j.eswa.2009.02.088

Norazah, M. S. (2013). Green products purchases: Structural relationships of consumers' perception of eco-label, eco-brand and environmental advertisement. Journal Sustainable Science and Management, 8(1), 1-10.

Oliver, J. D., \& Lee, S. H. (2010). Hybrid car purchase intentions: A cross-cultural analysis. Journal of Consumer Marketing, 27(2), 96-103. doi:10.1108/07363761011027204

Pagiaslis, A., \& Krontalis, A. K. (2014). Green consumption behavior antecedents: Environmental concern, knowledge, and beliefs. Psychology and Marketing, 31(5), 335-348. doi:10.1002/mar.20698

Patrick, H., Ibanez, V. A., \& Sainz, F. J. F. (2005). Green branding effects on attitude: Functional vs emotional positioning strategies. Marketing Intelligence and Planning, 23(1), 9-29. doi:10.1108/02634500510577447

Paul, J., Modi, A., \& Patel, J. (2016). Predicting green product consumption using theory of planned behavior and reasoned action. Journal of Retailing and Consumer Services, 29, $123-$ 134. doi:10.1016/j.jretconser.2015.11.006

Rios, F. J. M., Martinez, T. L., Moreno, F. F., \& Soriono, P. C. (2006). Improving attitudes toward brands with environmental associations: An experimental approach. Journal of Consumer Marketing, 23(1), 26-33. doi:10.1108/07363760610641136

Schiffman, L. G., \& Kanuk, L. L. (2000). Consumer behavior (7th ed.). Upper Saddle River, New Jersey: Prentice-Hall.

Smith, S., \& Paladino, A. (2010). Eating clean and green? Investigating consumer motivations towards the purchase of organic food. Australasian Marketing Journal, 18(2), 93-104. doi:10.1016/j.ausmj.2010.01.001

Solomon, M. R. (2014). Consumer behavior: Buying, having, and being (11th ed.). Upper Saddle River, NJ: Pearson Education Inc.

Suki, N. M. (2016). Green product purchase intention: Impact of green brands, attitude, and knowledge. British Food Journal, 118(12), 2893-2910. doi:10.1108/BFJ-06-2016-0295

Teng, C. C., \& Wang, Y. M. (2015). Decisional factors driving organic food consumption Generation of consumer purchase intentions. British Food Journal, 117(3), 1066-1081. doi:10.1108/BFJ-12-2013-0361

Teng, L. (2009). A comparison of two types of price discounts in shifting consumers' attitude and purchase intentions. Journal of Business Research, 62(1), 14-21. doi:10.1016/j.jbusres.2007.11.014

Wang, H. J. (2016). Green brand positioning in the online environment. International Journal of Communication, 10(1), 1405-1427.

Yadav, R., \& Pathak, G. S. (2016). Young consumers' intention towards buying green products in a developing nation: Extending the theory of planned behavior. Journal of Cleaner Production, 135, 732-739. 